
\title{
26 Research Square \\ Distribution of Oil, Grease and Petroleum \\ Hydrocarbons in Coastal Water and Sediments of Suez Bay
}

Randa Elmorsi ( $\nabla$ rrelmorsi@hotmail.com )

National Institute of Oceanography and Fisheries, NIOF, Marine Chemistry Department, Egypt

Research

Keywords: Permanganate Index, Oil and Grease, Polycyclic Aromatic Hydrocarbon, Pollution, Coastal Suez Bay Water

Posted Date: April 6th, 2021

DOl: https://doi.org/10.21203/rs.3.rs-367534/v1

License: (c) (1) This work is licensed under a Creative Commons Attribution 4.0 International License.

Read Full License 


\section{Abstract}

Permanganate index $(\mathrm{PI})$, oil and grease $(\mathrm{O} \& \mathrm{G})$ and 17 polycyclic aromatic hydrocarbons (PAHs) were tested in 13 sites of surface sediment and water samples collected from the western coast of Suez Bay (SB). $\mathrm{PI}$ and $\mathrm{O} \& \mathrm{G}$ in the $\mathrm{SB}$ coastal seawater ranged from $9.6 \mathrm{mg} \mathrm{O}_{2} \mathrm{~L}^{-1}$ and $17.0 \mathrm{mg} \mathrm{L}^{-1}$ to $16.0 \mathrm{mg} \mathrm{O}_{2}$ $\mathrm{L}^{-1}$ and $37.0 \mathrm{mg} \mathrm{L}^{-1}$, respectively. Petroleum aromatic hydrocarbon levels of water and sediment in the area offshore of SB have been determined by Gas Chromatography. The concentration ranged from 0.574 to $16873.2 \mathrm{ng} \mathrm{g}^{-1}$ in sediment and 0.502 to $43.540 \mathrm{ng} \mathrm{L}^{-1}$ in water. The observed data were compared with values reported in the literature. The possible source of pollution was also identified by using gas chromatographic analysis of the samples.

\section{Introduction}

Polycyclic aromatic hydrocarbons (PAHs) are among the most dangerous environmental chemical pollutants. Although, very low content of petroleum hydrocarbons $<1 \mathrm{ng} \mathrm{mL}^{-1}$ boosts photosynthesis in seawater while a progressive decrease of photosynthesis in algal cultures occurs at higher concentrations [1]. The PAHs solubility decreases in aqueous media with increasing molecular mass resulting in their low concentration in water compared with sediment. The PAHs naphthalene (NAP), acenaphthene (ACE), fluorine (FLU), phenanthrene (PHE), anthracene (ANT), pyrene (PYR), fluoranthene (FLA) and benzo[a]pyrene (bPYR), were classified as dangerous pollutants among other PAH's by the United States Environmental Protection Agency (USEPA) and World Health Organization (WHO) [2]. Due to their carcinogenic characteristics and mutating influence, their concentration levels should be periodically monitored in different matrices. They mainly originate from incomplete fossil fuel combustion and the release of petroleum and petroleum products [3]. They exist wherever oil is produced, transported, stored, processed or used at sea or land. The major sources of petroleum hydrocarbon input are the operation of tankers, refinery effluents, lubricants and other oils discard; accidents and offshore exploration.

The Gulf of Suez extends (GOS) from the Suez city at the north to Shadwan Island at the south over about a length of $320 \mathrm{~km}$. It represents the west northern stretch of the Red Sea with an average width of $50 \mathrm{~km}$. The Suez Bay (SB) is a shallow extension of the GOS, roughly elliptic in shape, with its major axis in the NE - SW direction (supplementary data (S1)). The average length along major axis is about $13.2 \mathrm{~km}$ while its average width along minor axis is about $8.8 \mathrm{~km}$. The mean depth is $10 \mathrm{~m}$, and the horizontal surface area is about $77.13 \mathrm{~km} 2$. The SB is connected to the GOS through most of its south eastern side, where a channel is dredged to a depth of $20 \mathrm{~m}$ to serve navigation purposes, and it is connected to the Suez Canal by a dredged channel of $12 \mathrm{~m}$ depth through the north eastern side of the SB [4]. The circulation in the SB can be followed generally by following the proper characteristics of these two water types. It was stated that seawater is circulated in the SB counterclockwise by entering SB from the GOS on the eastern side (Sinai side) and leaving SB on the western side [5]. The growing activities of the western side harbors of SB have led to an increasing rate of shipping and urbanization wastes in the whole region. Such undesirable inflows disturb the ecological balance and worsen the quality of water for 
human use. For these reasons, continuous monitoring of the PAH's content in the SB is necessary. The present study present an evaluation of the present status of PAH levels in the water and sediments of the western coast of the SB.

\section{Materials And Methods}

\subsection{Site description}

The studied area, SB, is located on the north-western part of the Suez Gulf, Red Sea (supplementary data (S1)). The SB has two important harbors; Adabiyah and Port Tawfik and is susceptible to discharges from anthropogenic, trade and industrial activities that may influence its water quality. The SB also receives sewage and waste both from the city of Suez and from ships wait for shipment through the Suez Canal. Additionally, it receives wastes from the industrial complex south of the Suez, including oil refineries, fertilizer plant, power stations and other industries. All junks coming from the different sources are discharged directly or indirectly with or without treatment into the SB. These refuses contain very large variety of chemical residues including aromatic derivatives [6].

\subsection{Sampling Procedures}

The water and sediment samples were collected from 13 different sites in the western coast of SB as illustrated in supplementary data (S1). Surface water and offshore sediment (0-5 cm depth in the bottom surface) samples were collected during April 2018 and kept in the refrigerator at $4{ }^{\circ} \mathrm{C}$ according to the recommended techniques [7].

\subsection{Analytical techniques}

The permanganate index $(\mathrm{PI})$ and oil and grease (O\&G) were analyzed by following the standard methods [7]. Hexane was used to extract O\&G. PAHs were determined by using gas chromatography/flame ionization detector (GC/FID) as detailed in supplementary data (S2).

\subsection{Apparatus}

The examined samples were measured using a Hewlett Packard 5890 series II GC equipped with a flame ionization detector (FID).

\subsection{Statistical evaluation}

Pearson correlation bivariate two-tailed test was applied to evaluate the significant difference in the obtained PI, O\&G and PAHs results compared with water quality parameters of different study sites, recently reported [4], using SPSS software version 16.

\section{Results And Discussion}


$\mathrm{PI}$ is a good indication of the chemical oxygen demand (COD) representing almost $40 \%$ of the total COD in water including PAH [8]. The main components of $0 \& G$ values are the non-polar materials, which were also known as the petroleum-based hydrocarbons, and fatty compounds of bio-origin [9]. Figure (1) shows the distribution of $\mathrm{PI}$ and $\mathrm{O} \& \mathrm{G}$ in the SB coastal seawater, which are detailed in Table (S3). The highest observed PI value (16.0 mg O $\left.\mathrm{L}^{-1}\right)$ was in the site (1) whereas the lowest value $\left(9.6 \mathrm{mg} \mathrm{O}_{2} \mathrm{~L}^{-1}\right)$ in the site (2). The highest value of $\mathrm{PI}$ in the site (1) may be due harbor activities in the naval base. The average value was $12.4 \mathrm{mg} \mathrm{O}_{2} \mathrm{~L}^{-1}$, which is slightly lower than the oxydisable organic matter values reported for SB in $2013\left(17.1-18.87 \mathrm{mg} \mathrm{O}_{2} \mathrm{~L}^{-1}\right)$ [10], but it is remarkably lower than COD values reported in 2013 in Suez Gulf $\left(36.8-296 \mathrm{mg} \mathrm{O}_{2} \mathrm{~L}^{-1}\right)[11]$ and that reported for seawater near Damietta Port (22.5 $\left.585 \mathrm{mg} \mathrm{O}_{2} \mathrm{~L}^{-1}\right)[12]$. This findings indicates the improvement of water quality criteria in SB.

The highest $O \& G$ value $\left(37.0 \mathrm{mg} \mathrm{L}^{-1}\right)$ was observed in the site (6) then sites (12) and (2) whereas the lowest value $\left(17.0 \mathrm{mg} \mathrm{L}^{-1}\right)$ in the site (1). The highest value of $O \& \mathrm{G}$ may be attributed to the harbor activities of Port Tawfik and Attaka and the poorly treated waste effluents of Nasr Petroleum Company (NPC). The NPC was reported to discharge oily wastewater into the Gulf of Suez with a discharge rate of $360000 \mathrm{~m}^{3} /$ day. Suez Petroleum Manufacturing Co. (SPMC) was reported to have the water quality of their effluent almost in conformity with the restrictions of effluent standards in Egypt. However, $6060 \mathrm{~kg}$ of O\&G flows daily in the receiving waters [13]. The average value was $25.6 \mathrm{mg} \mathrm{L}^{-1}$, which is lower than values obtained in 2016 (81.7 $\left.\mathrm{mg} \mathrm{L}^{-1}\right)$ for the region from Port Tawfik to El Ain Sokhna [14]. However, the present values of $O \& G$ are within those obtained in spring and summer of 2013-2014 (14.7-28.0 mg L-1) in SB [10]. These fluctuation along the period from 2013-2018 may indicate the increasing efforts of water treatment compared with the increasing marine activities within the same period 2001-2019 [15]. However, more efforts should be given to reduce the $O \& G$ values to lower than the standard value stated for oily mixtures discharged from ships and unclean ballast water discharged from oil tankers, specified by the Law No. 4 [13].

\subsection{Assessment of polycyclic aromatic hydrocarbon}

The investigated PAH were 17 compounds; naphthalene (NAP), acenaphthene (ACE), acenaphthylene (ACEL), fluorine (FLU), phenanthrene (PHE), anthracene (ANT), carbazole (CAR), fluoranthene (FLA), pyrene (PYR), benzo(a)anthracene (ANT), chrysene (CHR), benzo(b)fluoranthene (bbFLA), benzo(k)fluoranthene (bkFLA), benzo[a]pyrene (bPYR), dibenzo(a,b)anthracene (dbANT)), indeno(1,2,3$\mathrm{c}, \mathrm{d}$ )pyrene (inPYR) and benzo(g,h,i)perylene (bPRL). In water the PAH values (Figure 3 ) ranges from 0 (below detection limit) in sites (5) Pelgrim Village and (10) NIOF to $114.0 \mathrm{ng} \mathrm{L}^{-1}$ (47.11\% of the total PAH in the studied area) in the site (12) Attaka due to fisher boating. The 17 PAHs were distributed in water with the highest existence for PYR (34.52\%), FLU (28.19\%) and CHR (11.46\%) whereas the CAR was totally absent. 
The present highest values of NAP, ACE, ACEL, FLU, PHE, ANT, CAR, FLA, PYR, bANT, CHR, bbFLA, bkFLA, bPYR, dbANT, inPYR and bPRL in water; 1.41, 0.42, 1.80, 3.37, 2.95, 1.47, 0, 43.5, 42.3, 10.2, 9.89, 5.00, $1.96,1.83,2.36,1.63$, and $0.82 \mathrm{ng} \mathrm{L}^{-1}$ and their mean values $0.27,0.03,0.41,0.48,0.28,0.11,0,5.24,6.43$, $1.45,2.13,0.88,0.15,0.15,0.33,0.21$ and $0.06 \mathrm{ng} \mathrm{L}^{-1}$ in the water of the studied SB sites were lower than reported values such as 5.74, 2.73, 2.79, 4.85, 7.54, 3.45, 22.50, 16.47, 32.63, 8.82, 7.68, 10.58, 5.10, 16.61, 6.64 and 19.06 ng L $^{-1}$ for NAP, ACEL, ACE, FLU, ANT, PHE, FLU, PYR, bANT, CHR, bbFLU, bkFLU, bPYR, dbANT, bPRL and inPYR, respectively, in Suez Canal within Suez region [16]. The present total PAHs ND - $114.00 \mathrm{ng} \mathrm{L}^{-1}$ were also remarkably lower than the reported values in Suez Canal (992.56 ng L-1) and Alexandria port (1364.59 $\left.\mathrm{ng} \mathrm{L}^{-1}\right)$ but are still 10 times higher than that of the Sea of Japan [17].

The level of polyaromatic hydrocarbon in sediments (Figure 4) ranged from zero (below detection limit) in sites (10) NIOF and (13) Adabiya to $17669.34 \mathrm{ng} \mathrm{g}^{-1}$ (40.46\% of the total PAH in the studied area) in the site (9) influenced by discharges of Attaqa Electrical Station. The major component of PAHs in the sediments was from CHR representing $91.93 \%$ (40141.42 $\mathrm{ng} \mathrm{g}^{-1}$ ) of the $17 \mathrm{PAHs}$, which is one of the natural components in coal tar. Chrysene is a 4-ring member produced as smoke during partial combustion of coal, gasoline, junk, animal, and plant resources that may explain its presence near Attaqa Electrical Station. The concentrations of PAHs in sediment have been formerly classified as low, moderate, high and very high polluted (0-100, 100-1000, 1000-5000, >5000 $\mathrm{ng} \mathrm{g}^{-1}$ [18]. Therefore, the surface sediments of Suez Bay can be classified to be low to be very highly contaminated in sites (8), (9) and (12).

For those sites where the concentrations were lower, it could be attributed to be the far distance from the point source occasioned with continuing dilution of the pollutant. The upstream sites were reported to record low concentrations of these pollutants probably due to dilution in the flow of water toward that direction [19]. On contrary, the high concentrations recorded in some sites could be ascribed to the closeness of such sites to point source such as heavy shipment of oil tanker and oil drilling activities concentrated at these regions.

The present mean values of NAP, ACE, ACEL, FLU, PHE, ANT, CAR, FLA, PYR, bANT, CHR, bbFLU, bkFLU, bPYR, dbANT. inPYR and bPRL in sediments; ND, 1.36, ND, 1.61, 7.58, 12.49, 19.43, 2.85, 116.91, 17.67, $3087.80,12.80,59.15,11.05,2.27,1.76,4.12 \mathrm{ng} \mathrm{g}^{-1}$, respectively, in the sediment samples of the studied SB sites were lower than reported values such as 14.03, 28.93, 38.69, 21.94, 87.99, 15.54, 125.08, 68.32, 104.08, 62.99, 35.05, 21.60, 37.43, 18.56, 25.89 and $12.89 \mu \mathrm{L} \mathrm{L}^{-1}$ for NAP, ACE, ACEL, FLU, PHE, ANT, FLU, PYR, CHR, bANT, bPYR, dbANT, bbFLU, bkFLU, bPRL and inPYR, respectively, in Suez Gulf [20]. The present total PAHs ND - $17669.00 \mathrm{ng} \mathrm{g}^{-1}$ were also remarkably lower than the reported values in Suez Gulf (195.53 - $\left.1189.3 \mu \mathrm{g} \mathrm{g}^{-1}\right)$ [20] and Alexandria port (88 to $\left.6338 \mathrm{ng} \mathrm{g}^{-1}\right)$ [21].

Comparing the major PAHs found in water and sediments, CHR was observed to retreat to the third highest concentration in water beyond PYR and FLU compared with sediment in which $\mathrm{CHR}$ with the 
major PAH. This may be attributed to the very low solubility of CHR in water $\left(0.002 \mathrm{mg} \mathrm{L}^{-1}\right)$ compared with PYR $\left(0.135 \mathrm{mg} \mathrm{L}^{-1}\right)$ and FLU $\left(0.260 \mathrm{mg} \mathrm{L}^{-1}\right)$ [22].

\subsection{Source identification of PAHs in SB}

The most important sources of PAHs in the marine environment are either petrogenic or pyrogenic. Petrogenic source originates from natural drain of petroleum or petroleum products into the environment, while pyrogenic originates from imperfect combustion of fossil fuels [23]. PAHs in literature were divided into the low molecular weight PAHs (LPAHs) / high molecular weight (HPAHs) ratio. The LPAHs include two to three rings whereas the HPAHs comprise four to six rings and are extremely carcinogenic [24]. With LPAHs/HPAHs > 1 indicates petrogenic while less than one indicates pyrogenic [25]. In the present seawater results for all 13 sites the ratios were less than one which is suggesting a pyrogenic origin prevalence of PAHs except for sites (2) and (4) where no existence was recorded for HPAHs indicating petrogenic origin whereas in sediment all 13 sites show LPAHs/HPAHs ratios less than one indicating a pyrogenic origin of PAHs as detailed in Table (2).

Furthermore, some molecular indices play a major role in establishing the origin of PAHs, e.g. PHE/ANT ratio among three-ring isomers and flourantherene/PYR ratio among four-ring isomers. They were chosen according to their thermodynamic stability; PHE and flouanthene are thermodynamically more stable. Thus, the PHE/ANT ratio of pyrogenic PAH assemblages usually are less than five and the petrogenic ratios usually are greater than five. The FLU/PYR ratio usually approaches or exceeds a value of one in pyrogenic assemblages and usually is substantially less than a value of one in petrogenic PAH assemblages [26]. According to the results in Table (S4), the PHE/ANT ratios are mainly lower than five in all sites, except for in water of site 12, which indicates a dominant pyrogenic nature of PAHs in sediments and water of SB, due industrial as well as shipment activities, which is in agreement with the conclusion taken from the above LPAHs/HPAHs ratios. On contrary, the flourantherene/PYR ratios exceeded one only at the sites 6, 8 and 11 that confirm the pyrogenic origin of PAHs in these sites, whereas the differences may be due to the continuous counter clockwise circulation of water in the SB [5].

\subsection{Statistical evaluation of results}

The present PAHs contents in water and sediments of SB were statistically compared with the water quality parameters recently published for the same samples [4]. Significant correlation was interestingly obtained between the TPAH in sediments and temperature of water that may indicate that the source of PAHs is influenced with a heat source such as cooling water. PI was also found negatively correlated with the chlorophyll (a) in water. This is an important indication that the presence of oxydisable matter is the cause of decrease in chlorophyll production [27]. The detailed statistical evaluation can be accessed in supplementary data as $\mathrm{S} 4$.

\section{Conclusion}


In this study, $\mathrm{Pl}, 0 \& \mathrm{G}$ and 17 polycyclic aromatic hydrocarbons (PAHs) were tested in 13 sites of surface sediment and water samples collected from the western coast of Suez Bay. The pollution levels of the studied pollutants were observed to be lower than previous reports. PI and O\&G in the SB coastal seawater ranged from $9.6 \mathrm{mg} \mathrm{O}_{2} \mathrm{~L}^{-1}$ and $17.0 \mathrm{mg} \mathrm{L}^{-1}$ to $16.0 \mathrm{mg} \mathrm{O}_{2} \mathrm{~L}^{-1}$ and $37.0 \mathrm{mg} \mathrm{L}^{-1}$, respectively. The results also indicated that the total PAH levels in sediments samples ranged from ND to $17669.00 \mathrm{ng} \mathrm{g}^{-1}$ and ND to $114.00 \mathrm{ng} \mathrm{L}^{-1}$ in water samples. The identification of the source based on the results obtained from several diagnostic ratios suggested pyrogenic source for PAHs in the studied water and sediment samples. The qualitative and quantitative assessment of PAHs in water and sediments samples of SB indicated that they are affected by PAHs pollution. Statistical evaluation suggests that the presence of oxydisable matter is the cause of decrease in chlorophyll production, which is challenging due to the organic matter especially PAHs tendency to initiate carcinogenic and or mutagenic effects in earthly as well as aquatic biota.

\section{Declarations}

\section{Availability of data and materials}

The author declares the availability of data and materials.

2. Competing interests

The author declares no competing interests.

3. Funding

The author declares no funding.

\section{Authors' contributions}

All of the researches within this article were carried by RE. RE collected the samples. RE analyzed and interpreted the data. RE write, read and approved the final manuscript.

\section{Acknowledgements}

Not applicable.

\section{References}

[1] O'Brien PPY, Dixon PS. The effects of oils and oil components on algae: A review. Br Phycol J 1976;11:115-42. doi:10.1080/00071617600650161.

[2] Yan J, Wang L, Fu PP, Yu H. Photomutagenicity of 16 polycyclic aromatic hydrocarbons from the US EPA priority pollutant list. Mutat Res - Genet Toxicol Environ Mutagen 2004;557:99-108. 
doi:10.1016/j.mrgentox.2003.10.004.

[3] Ahmed OE, Mahmoud SA, Mousa AER. Aliphatic and Poly-Aromatic Hydrocarbons Pollution at the Drainage Basin of Suez Oil Refinery Company. Curr Sci Int 2015;4:27-44.

[4] Elmorsi RR, El-Alfy MA, Abou-El-Sherbini KS. Evaluation of the trophic state predicted from lab and Landsat data of western coastal water of Suez Bay, Egypt. GeoJournal 2020. doi:10.1007/s10708-02010230-3.

[5] Abou-el-sherbini KS, Hamed MA. Pollution assessment in aquatic ecosystem along the western coast of the Suez Bay. Egypt J Aquat Biol Fish 2000;4:37-59.

[6] Belal AAM. Macro-benthic invertebrates as a bio-indicator for water and sediment quality in Suez Bay , Red Sea. Egypt J Aquat Res 2019. doi:10.1016/j.ejar.2019.03.003.

[7] APHA/AWWA/WEF. Standard Methods for the Examination of Water and Wastewater. American Public Health Association, American Water Works Association, Water Environment Federation; 1999. doi:ISBN 9780875532356.

[8] Zeng Y, Li L, Zhao H. The Correlation Analysis of COD and Permanganate Index in Jiuzhaigou Water Environment 2014;933:994-8. doi:10.4028/www.scientific.net/AMR.933.994.

[9] Adeniji AO, Okoh 00, Okoh Al. Analytical methods for the determination of the distribution of total petroleum hydrocarbons in the water and sediment of aquatic systems: A review. J Chem 2017;2017. doi:10.1155/2017/5178937.

[10] Soliman YA, El_Gawad IA, Abdallah AM. EVALUATION LEVELS OF PHENOLS AND ITS DERIVATIVES IN SUEZ BAY SEAWATER. Glob Sci J 2017;5:202.

[11] Emara MM, Farid NA, Ahmed OE, Kamal EM. Physico-chemical Study of Surface Seawater in The Northwestern Gulf of Suez. Egypt J Chem 2013;56:345-65.

[12] Environmental Impact Assesment (EIA) for a Proposed Mathanol Facility in Damietta Port (Draft Report). vol. 20. 2006.

[13] STATE OF OIL POLLUTION AND MANAGEMENT IN SUEZ GULF REGION. REGIONAL ENVIRONMENTAL MANAGEMENT IMPROVEMENT PROJECT (REMIP) WORKING GROUP 2 (WG2); 2008.

[14] Alsayed Abdo Mohamed Eed M, Mona Foad Kaiser prof. Monitoring of Oil Spills along Suez-Ain Sokhna Coastal Zone, Using Remote Sensing Techniques. IOSR J Environ Sci 2016;10:6-16. doi:10.9790/2402-10210616.

[15] Egypt GDP: Suez Canal 2020:1-9. https://www.ceicdata.com/en/egypt/gdp-by-industry-currentprice/gdp-suez-canal. 
[16] Al-Agroudy N, Soliman YA, Hamed MA, Zaghloul G. Distribution of PAHs in Water, Sediments Samples of Suez Canal During 2011. J Aquat Pollut Toxicol 2017;1:1-10.

[17] Honda M, Suzuki N. Toxicities of polycyclic aromatic hydrocarbons for aquatic animals. Int J Environ Res Public Health 2020;17. doi:10.3390/ijerph17041363.

[18] Baumard P, Budzinski H, Garrigues P. Environmental Chemistry POLYCYCLIC AROMATIC HYDROCARBONS IN SEDIMENTS AND MUSSELS OF THE. Environ Toxicol 1998;17:765-76.

[19] Nwineewii JD, Marcus AC. Polycyclic Aromatic Hydrocarbons (PAHs) In Surface Water and Their Toxicological Effects in Some Creeks of South East Rivers. Environ Sci Toxicol Food Technol 2015;9:2730. doi:10.9790/2402-091222730.

[20] Azab AM, Shaban WM, Zaki MS, Authman MMN, Zaher MFA. Monitoring of Petroleum Hydrocarbons in Sediment and Gastropods from Suez Gulf, Red Sea. Life Sci J 2012;91:1689-99. doi:10.1017/СBO9781107415324.004.

[21] Nemr A El, Said TO, Khaled A, El-Sikaily A, Abd-Allah AMA. The distribution and sources of polycyclic aromatic hydrocarbons in surface sediments along the Egyptian Mediterranean coast. Environ Monit Assess 2007;124:343-59. doi:10.1007/s10661-006-9231-8.

[22] Lu GN, Dang Z, Tao XQ, Yi XY. Estimation of water solubility of polycyclic aromatic hydrocarbons using quantum chemical descriptors and partial least squares. QSAR Comb Sci 2008;27:618-26. doi:10.1002/qsar.200710014.

[23] Tobiszewski M, Namieśnik J. PAH diagnostic ratios for the identification of pollution emission sources. Environ Pollut 2012;162:110-9. doi:10.1016/j.envpol.2011.10.025.

[24] Younis AM, Soliman YA, Elkady EM, El-Naggar MH. Assessment of polycyclic aromatic hydrocarbons in surface sediments and some fish species from the gulf of suez, egypt. Egypt $J$ Aquat Biol Fish 2018;22:49-59. doi:10.21608/ejabf.2018.12472.

[25] Zhang J, Fan S, Du X, Yang J, Wang W, Hou H. Accumulation, allocation, and risk assessment of polycyclic aromatic hydrocarbons (PAHs) in soil-brassica chinensis system. PLoS One 2015;10:1-16. doi:10.1371/journal.pone.0115863.

[26] Neff JM, Stout SA, Gunster DG. Ecological risk assessment of polycyclic aromatic hydrocarbons in sediments: identifying sources and ecological hazard. Integr Environ Assess Manag 2005;1:22-33. doi:10.1897/IEAM_2004a-016.1.

[27] Yang X, Wu X, Hao H, He Z. Mechanisms and assessment of water eutrophication. J Zhejiang Univ Sci B 2008;9:197-209. doi:10.1631/jzus.B0710626. 
Figures

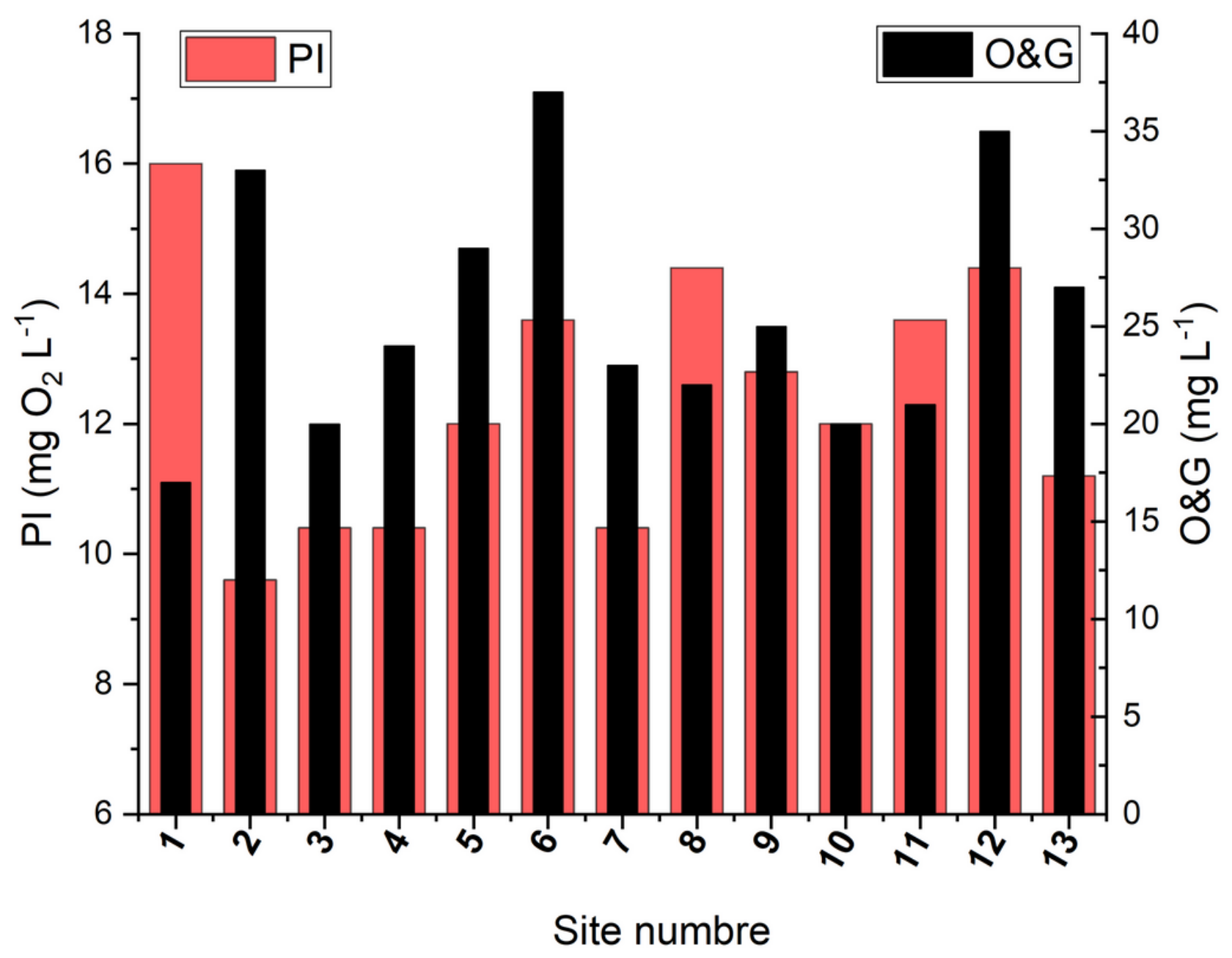

Figure 1

Variation of permanganate indices $(\mathrm{Pl}, \mathrm{mg} \mathrm{O} 2 \mathrm{~L}-1)$ and oil and grease (O\&G, mg L-1) along the western coastal waters of Suez Bay. 


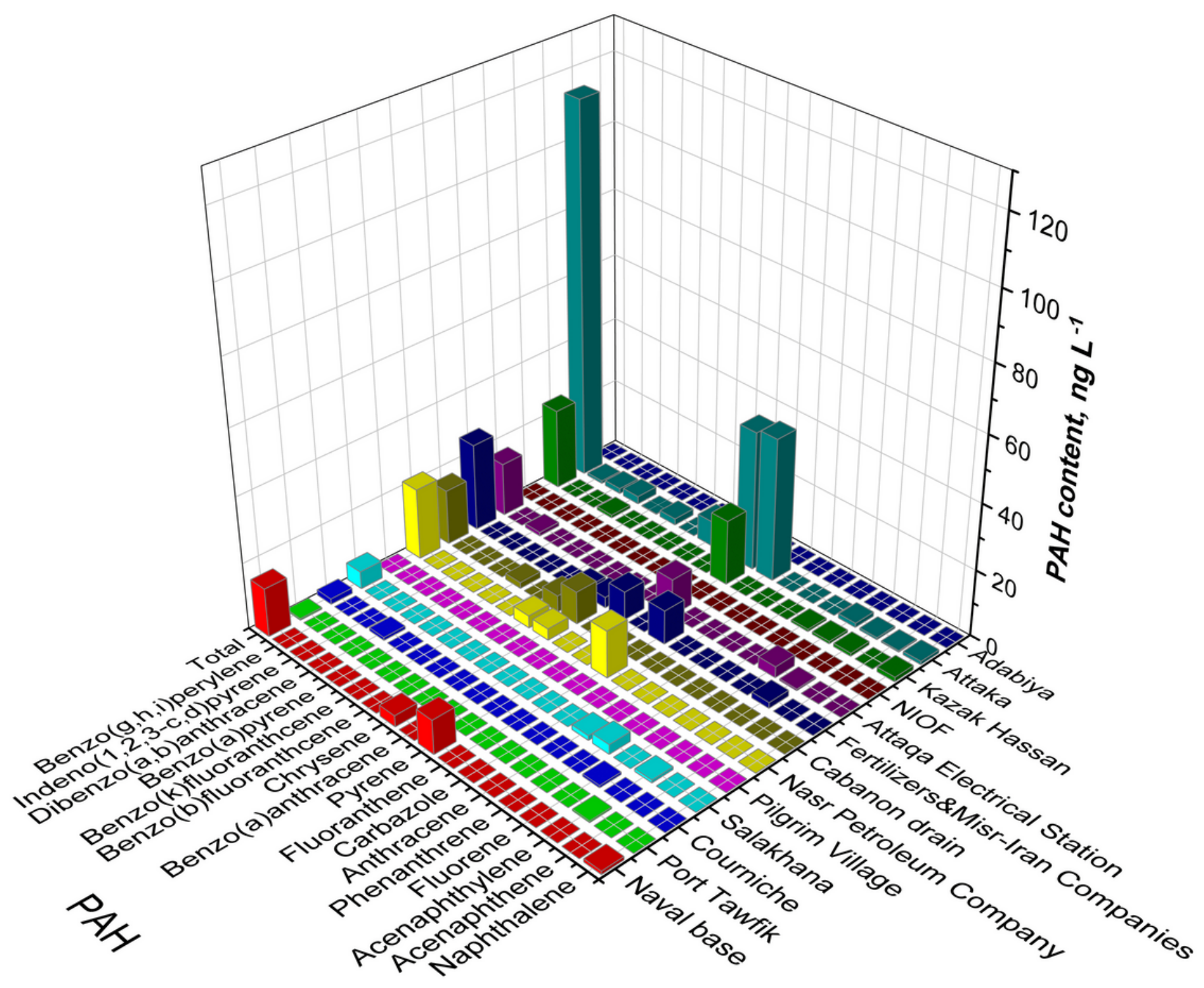

Figure 2

Concentration of PAHs from different sites in offshore water of Suez Bay western coast during 2018 in ng $\mathrm{L}-1$ 


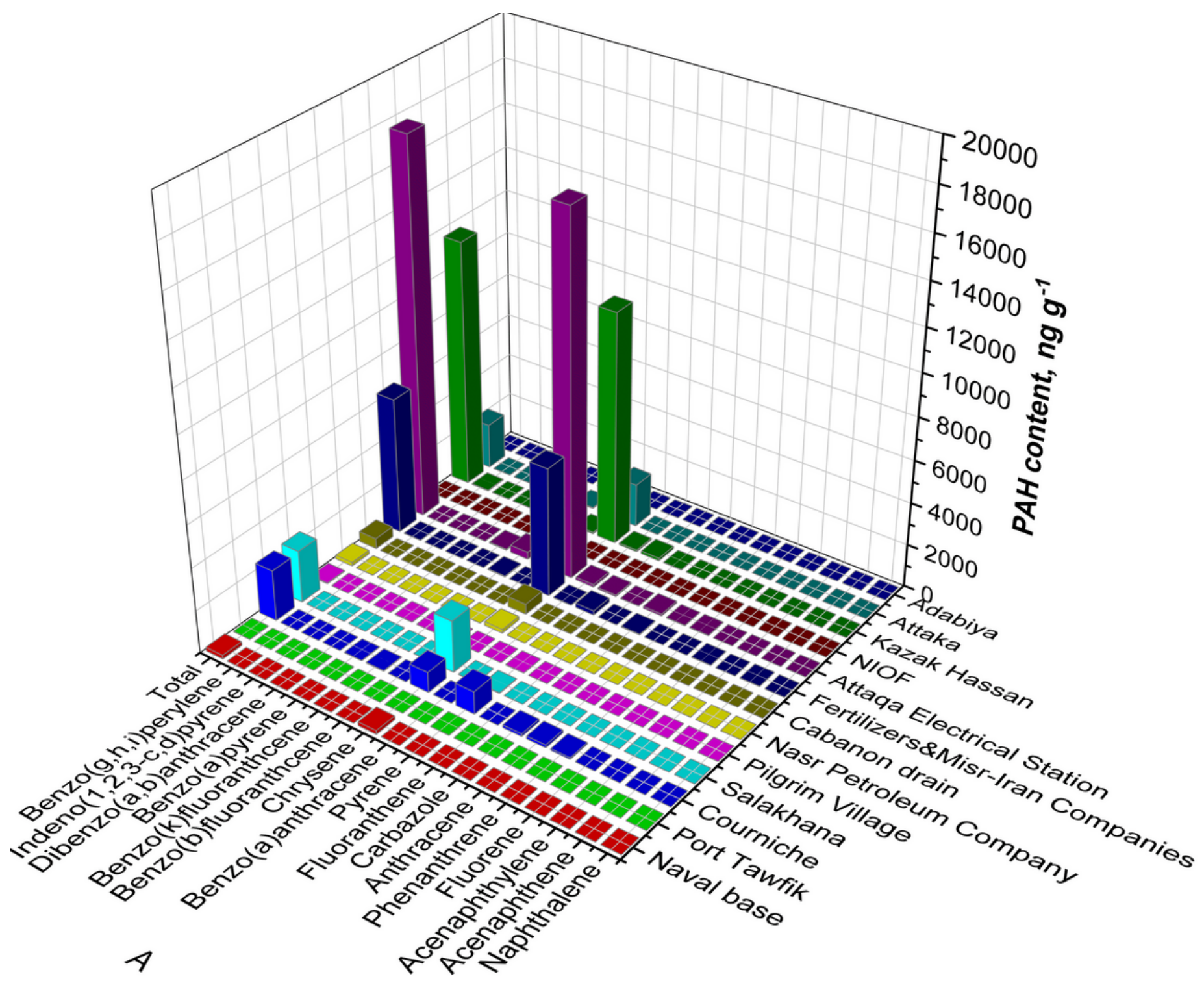

Figure 3

Concentration of PAHs from different sites in offshore sediments of Suez Bay western coast during 2018 in $\mathrm{ng} \mathrm{g}-1$

\section{Supplementary Files}

This is a list of supplementary files associated with this preprint. Click to download.

- Supplementarydata.docx 